\title{
Reproductive Technique
}

National Cancer Institute

\section{Source}

National Cancer Institute. Reproductive Technique. NCI Thesaurus. Code C19166.

Techniques used in human and animal reproduction. 